\title{
PROTECTING CREATIVITY: WhY MORAL RighTS SHOULD BE EXTENDED TO SOUND RECORDINGS UNDER NEW ZEALAND COPYRIGHT LAW
}

\author{
Nicholas Stuart Wood ${ }^{*}$
}

Traditionally, moral rights have not extended to the creators of sound recordings under either common law or civil law systems. The somewhat outdated rationale of this exclusion of sound recordings from the ambit of moral rights protection was generally that sound recordings were merely mechanical reproductions of already existing musical works, and hence the recordings lacked sufficient creativity to make them worthy of moral rights protection. In 1996, the WIPO Performances and Phonograms Treaty sought to remedy this anomaly in copyright law by extending the moral rights of paternity and of integrity to performers whose performances are fixed in sound recordings.

This paper argues that New Zealand should follow WIPO's lead and extend the moral rights provisions of the Copyright Act 1994 to sound recordings. The author argues that sound recordings are imbued with sufficient creativity to merit moral rights protection and that this protection should be granted not only to performers but to sound engineers and producers, who also contribute creatively to the recording. This paper examines how moral rights in relation to sound recordings might work in practice and what remedies should be available for breach of these rights. The author concludes that the extension of moral rights to sound recordings need not impact detrimentally on the music industry, as some commentators fear.

\section{INTRODUCTION}

Music is the fourth great material want of our nature-first food, then raiment, then shelter, then music—Christian Nestell Bovee (United States author and lawyer, 1820-1904). ${ }^{1}$

* This paper was submitted in fulfilment of the LLB(Hons) requirements at Victoria University in 2000 . 
As Christian Nestell Bovee observes, albeit with a little hyperbole, music has always played an important role in human existence. However, the advent of processes for recording and reproducing musical performances has given music a greater prominence in western society than even before. Radio and portable stereos have made music a ubiquitous presence in everyday life. The rise of recorded music in western society has also seen the rise of a sizeable music industry, where record companies work with performers to quench the public's thirst for a good tune.

As with any partnership, however, differences can arise between the performers and their record companies over the vision each has for a particular recording. One such difference arose this year, when a "Greatest Hits" compact disc of 18 songs was released for the Little River Band, a popular Australian rock band from the 1970s and 1980s. Whether by accident or by design, the record company released versions of two tracks on the CD that differed slightly from how the tracks sounded when they were originally released. Although the record company, as owner of the copyright in the recordings, is free to release these different versions to the public, the Little River Band may well protest that their recordings are not being released the way that the band originally intended them to sound. In this situation, do performers have any legal course of redress against the copyright owner?

At first blush, the band might appear to have a course of redress under the moral rights branch of copyright law. ${ }^{2}$ Moral rights, which were one of the major changes introduced into the New Zealand copyright regime in $1994,{ }^{3}$ can be described as a residue of rights left with an author once the copyright in the work is sold. Generally, this residue comprises the right to be recognised as author of the work (the right of paternity) and the right to object to significant changes in the work's nature (the right of integrity). Although French jurisprudence has recognised moral rights since the nineteenth century, ${ }^{4}$ Anglo-American jurisdictions have been reluctant to admit moral rights into copyright law until very recently. ${ }^{5}$

1 Ralph E Browns (ed) The New Dictionary of Thoughts (Standard Book Company, New York, 1961) 430.

2 Record companies often require performers (or songwriters) to waive these moral rights so that the record company is left free to exploit the sound recording as it sees fit. However, further discussion of waivers is postponed until Part III E of this paper.

3 Copyright Act 1994, ss 94-110.

4 J A L Sterling World Copyright Law (Sweet \& Maxwell, London, 1998) 280 [World Copyright Law].

5 W R Cornish "Authors in Law" (1995) 58 MLR 1. Note the exception of Canada, which adopted moral rights in 1931. 
One consequence of the relatively recent reception of moral rights into common law jurisprudence is that these rights have been cautiously limited to those categories of work that traditionally receive moral rights protection in continental Europe. The problem for performers such as the Little River Band in the introductory example is that moral rights do not attach to sound recordings, as distinct from the musical work performed in the recording. ${ }^{6}$ The present author believes that the current lack of moral rights in relation to sound recordings represents a deficiency in intellectual property law, and the focus of this research paper rests entirely on this problem.

For various reasons, few countries have ever legislated for moral rights in respect of sound recordings. ${ }^{7}$ In continental Europe, sound recordings have never qualified for moral rights protection (or even, traditionally, for economic protection) because they are seen as lacking sufficient creativity. ${ }^{8}$ By contrast, common law jurisdictions, although quick to protect sound recordings, ${ }^{9}$ scarcely recognised moral rights at all. However, this reluctance in both civil and common law jurisdictions to accord moral rights to sound recordings may be about to change.

On 20 December 1996, the World Intellectual Property Organisation (WIPO) signed the WIPO Performances and Phonograms Treaty (the Treaty) and opened it up for ratification by WIPO member states. ${ }^{10}$ The Treaty, which is not yet in force, would bind member states to provide various rights to performers and to phonogram producers, such as the right to

6 The categories of work that receive moral rights protection in New Zealand are literary, artistic, dramatic and musical works, as well as films: Copyright Act 1994, ss 94(1), 98(2) and 102(2).

7 The Hungarian and Slovenian copyright regimes are the only examples that the present author found of legislation that might potentially provide performers with moral rights as regards their sound recordings. Both countries provide performers with moral rights in relation to their "performances" (Copyright Act 1999 (Hungary), s 75) or in relation to any "use" of their performances (Copyright and Related Rights Act 1995 (Slovenia), art 120). Given that both countries have ratified the WIPO Performances and Phonograms Treaty 1996, which binds Contracting Parties to provide performers with moral rights in respect of their sound recordings, it appears likely that the Hungarian and Slovenian statutes could be construed consistently with this objective.

8 For example, sound recordings are not included within the fourteen categories of cuvre de l'esprit (or "creative work") protected in art L 112-2 of the French Intellectual Property Code 1992. In fact, sound recordings were not protected at all in France until 1985 and receive sui generis protection under arts L 211-1 to L 216-1 of the 1992 Code.

9 For example, section 19(1) of the Copyright Act 1911 (UK) provided that "[c]opyright shall subsist in records...in like manner as if such contrivances were musical works".

10 Daniel Gervais The TRIPS Agreement: Drafting History and Analysis (Sweet \& Maxwell, London, 1998) 97. 
rentals from phonograms, ${ }^{11}$ and the right to authorise reproduction and commercial distribution of phonograms. ${ }^{12}$

One of the most significant provisions of the Treaty is article 5(1), which requires member states to grant performers moral rights as regards their performances fixed in sound recordings. ${ }^{13}$ As this paper is essentially considering the consequences of $\mathrm{New}$ Zealand's adherence to this specific provision, it is convenient at the outset to reproduce the provision in its entirety:

Independently of a performer's economic rights, and even after the transfer of those rights, the performer shall, as regards his live aural performances or performances fixed in phonograms have the right to claim to be identified as the performer of his performances, except where omission is dictated by the manner of the use of the performance, and to object to any distortion, mutilation or other modification of his performances that would be prejudicial to his reputation.

As at 15 July 2000, 50 states had signed the Treaty, including the United States and the European Union, but only 16 of these states had ratified or acceded to it. ${ }^{14}$ This low rate of accession is significant, because the Treaty does not come into force until three months after 30 states have ratified or acceded to it. ${ }^{15}$ It should be noted, however, that the European Union has signed the Treaty on behalf of its fifteen member states. Ratification by all fifteen European Union member states would mean that 31 states would have ratified the Treaty and the Treaty would then come into force. Indeed, the United Kingdom is currently debating how to implement the Treaty under its law. ${ }^{16}$ It thus seems that New Zealand will soon need to consider providing for moral rights in relation to sound

11 WIPO Performances and Phonograms Treaty 1996, arts 9 (performers' right) and 13 (producers' right).

12 WIPO Performances and Phonograms Treaty 1996, arts 7-8 (performers' rights) and 11-12 (producers' rights).

13 World Copyright Law, above n 4, 295.

14 These sixteen states are: Argentina, Belarus, Burkina Faso, Costa Rica, Croatia, Ecuador, El Salvador, Hungary, Latvia, Mexico, Panama, Republic of Moldova, Saint Lucia, Slovakia, Slovenia and the United States.

15 WIPO Performances and Phonograms Treaty 1996, art 29.

16 The Copyright Directorate of the United Kingdom Patent Office has released a consultation paper on how best to implement article 5(1) of the Treaty in the United Kingdom: Copyright Directorate of the United Kingdom Patent Office Moral Rights for Performers: A Consultation Paper on Implementation in the United Kingdom of the WIPO Performances and Phonograms Treaty Obligation on Performers' Moral Rights and on Further Developments in WIPO on Performers' Moral Rights (London, 1999) 3. 
recordings to bring New Zealand copyright law into line with this developing overseas trend.

The extension of moral rights to cover sound recordings will be a new concept for most jurisdictions and one that will cause conceptual and practical difficulties for most. This paper seeks specifically to determine whether New Zealand should amend its copyright law to provide for moral rights in respect of sound recordings, as ratification of article 5(1) of the Treaty would require. Although the question can be put simply, there are numerous theoretical and practical problems that must be overcome before a successful and efficacious regime of moral rights protection for sound recordings could be instituted in New Zealand (or indeed in any other country). The fundamental principle from which this paper is argued is that sound recordings are imbued with sufficient skill, creativity and human spirit for them to be logically brought within the scope of moral rights protection.

This paper is divided into Parts, of which this introduction is the first. Although many of the issues canvassed in this paper are intertwined to some extent, this paper will treat each of the main issues individually for better clarity. Part II examines the threshold question of whether moral rights should, as a philosophical or conceptual matter, be extended to sound recordings. Part III analyses who should exercise any potential moral rights in a sound recording, an especial problem in the case of sound recordings, where numerous collaborators will generally have brought the recording into being. Although article 5(1) of the Treaty requires moral rights to be exercisable only by the performers of a sound recording, this paper will also examine whether sound engineers or other creative collaborators should be granted moral rights under New Zealand law. Part IV considers the various moral rights as they would relate to sound recordings, and tackles some of the practicalities of extending moral rights to the recording industry. Part V looks at what sort of relief should be given for breaches of moral rights in a sound recording. Part VI concludes this paper by arguing that moral rights should be given in New Zealand law to those who bring sound recordings into being, and that the difficulties in formulating a regime specifically for sound recordings, although significant, should not be overstated and can certainly be overcome.

\section{PHILOSOPHICAL AND CONCEPTUAL ARGUMENTS FOR EXTENDING MORAL RIGHTS TO SOUND RECORDINGS}

\section{A Creativity and the Ontology of Moral Rights}

To determine whether moral rights should be extended to sound recordings, it is first necessary to outline exactly what moral rights are and the conceptual basis for their existence. Most commentators draw a dichotomy in copyright law between "economic 
rights" on the one hand and "moral rights" on the other. ${ }^{17}$ Whereas the economic right protects authors' somewhat mercenary interest in profiting from the sale and reproduction of their creations, the ontology of the moral right stems from more noble considerations.

As noted in Part I, moral rights can be described as a residue of rights that remain with an author once the economic rights in the work have been transferred. Typically, two main rights are distinguished within the rubric of moral rights. ${ }^{18}$ The right of paternity lets authors claim authorship of their work. ${ }^{19}$ The right of integrity protects an author's work from any distortion, mutilation or modification that is prejudicial to the author's honour or reputation, even when another person has legitimately become the owner of the work. ${ }^{20}$

The author's retention of these rights after transfer of the copyright to a new owner might well be said to sit uncomfortably with traditional notions of property. J E Penner, attacking the Hohfeldian view of property as a "bundle of rights", defines property as "the right to determine how particular things will be used". ${ }^{21}$ The right to property thus entails a concomitant duty on non-owners of "non-interference" with the owner's own use of the thing. ${ }^{22}$ Moral rights certainly constitute an exception to this general duty of noninterference, because the moral right lets a non-owner of a work (which is essentially what the author is) dictate to the new owners what they may or may not do with the work. Absent contractual agreement, what possible justification could exist for such a curtailment of the new owners' rights?

The justification for an author's moral right lies in two philosophical movements that were very much in the ascendant in Europe during the latter half of the eighteenth century - the Enlightenment and Romanticism. During the course of the century, leading Enlightenment intellectuals began asserting the link between natural law and individual rights. Inspired by Locke, these philosophes stressed "'inalienable' and 'unalterable'

17 In reality, both sets of rights are to some extent economic in scope, as the exercise of moral rights will undoubtedly have some economic impact. See Gervais, above n 10, 72, where that author notes that excluding moral rights from the TRIPS Agreement is incongruous because, in fact, all uses or abuses of moral rights are to some extent trade-related.

18 Christopher Aide "A More Comprehensive Soul: Romantic Conceptions of Authorship and the Copyright Doctrine of Moral Right" (1990) 48 UT Fac L Rev 211,212. The rights of paternity and of integrity are the two moral rights that art 6bis of the Berne Convention has recognised since 1928. Civil law recognises other moral rights not adopted in the United Kingdom or New Zealand.

19 Copyright Act 1994, ss 94-97.

20 Copyright Act 1994, ss 98-101.

21 J E Penner The Idea of Property in Law (Clarendon Press, Oxford, 1997) 5.

22 Penner, above n 21, 128. 
individual freedom from control", ${ }^{23}$ an idea that provided a strong intellectual basis for the struggles against absolutist regimes that culminated in the American and French Revolutions towards the end of the century. ${ }^{24}$ With the French Revolution came the Declaration of the Rights of Man and Citizen, one of the first written acknowledgements of the concept of human rights. ${ }^{25}$ As regards intellectual property, this growing emphasis on individual rights is significant, because during the eighteenth century, it was the individual who came to be seen as "the source or origin" of intellectual creation. ${ }^{26}$

Influenced by this fervour for human rights, the revolutionary government in France passed laws in 1791 and 1793, conferring a copyright on authors by virtue of their inherent rights as humans, thereby replacing the ancien régime system where the Sovereign had conferred all intellectual property rights. ${ }^{27}$ Christopher Aide thus argues that moral rights, being rights that attach to the individual author, arose in part "from the spirit of these laws, and from the philosophy of individualism which infused the French Revolution". ${ }^{28}$

Also informing the development of moral rights was the literary movement of Romanticism, the roots of which can be traced to the latter half of the eighteenth century. ${ }^{29}$ Romanticism emphasised the bond between author and work for the first time in Western philosophy. ${ }^{30}$ More importantly, however, authors came to be seen as being on a "higher plane than the rest of humanity" because of the "totality of vision" with which authors infused their work. ${ }^{31}$ Drawing on the Romantic idea that the author occupied a preferred status in society, French judges began to develop a jurisprudence of moral rights from the

23 Paul Gordon Lauren The Evolution of International Human Rights: Visions Seen (University of Pennsylvania Press, Philadelphia, 1998) 15-16.

24 Lauren, above n 23, 17.

25 Lauren, above n 23, 17-18.

26 L Bentley and B Sherman The Making of Intellectual Property (Cambridge University Press, Cambridge, 1999) 35.

27 Aide, above n 18, 221.

28 Aide, above n 18, 221.

29 Aide, above n 18, 214-215.

30 Aide, above n 18, 214.

31 Aide, above n 18, 218. 
nineteenth century onwards. ${ }^{32}$ From this, John Merryman and Albert Elsen distil that the main justification for the protection of moral rights is thus: ${ }^{33}$

...the idea that the work of art is an extension of the artist's personality, an expression of his innermost being. To mistreat the work of art is to mistreat the artist, to invade his area of privacy, to impair his personality.

The emphasis of both the Enlightenment and Romanticism on the role of an individual human in bringing a work into being has played an important part in making creativity the sine qua non criterion for both moral rights and economic rights protection under the continental droit d'auteur system. ${ }^{34}$ Creativity is the decisive factor for judging what is worth protecting and what is not because creativity is the very thing that individual authors bring to their works, and droit d'auteur systems are quite literally about protecting an "author's right".

More importantly, the requirement of creativity in a work also explains much about the ontology of the moral right in civil law systems. In the French term for moral rights, droit moral, "moral" refers not to morality but to the intellectual aspect of a work. ${ }^{35}$ The moral right is thus a way of protecting authors' intellectual investment in their works. The important aspect to note, then, is that the moral right is exercisable only by those authors who are considered to have injected sufficient creativity into their works. By contrast, the moral right cannot attach to works that are seen to be lacking creativity or an intellectual aspect.

\section{B Creativity and Moral Rights in Sound Recordings}

The requirement in droit d'auteur systems for a certain level of creativity before authors can receive economic and moral rights protection for their works has played the decisive role in deciding the fate of sound recordings in the intellectual property regimes of civil law jurisdictions. Sound recordings are not protected under the droit d'auteur system because they are seen as lacking the creative or intellectual aspect necessary for protection. Instead, the makers of sound recordings have received economic rights under the "neighbouring rights" system, a system that provides economic rights analogous to those

32 Aide, above n 18, 221.

33 John Merryman and Albert Elsen Law, Ethics and the Visual Arts (2 ed, University of Pennsylvania Press, Philadelphia, 1987) 145.

34 See the creativity requirement of French law in art L 111-1 of the French Intellectual Property Code 1992, which grants authors protection only for "works of the mind".

35 Alain Rey (ed) Le Robert Micro (2 ed, Dictionnaires Le Robert, Paris, 1994) 821. The first meaning given for moral is "pertaining to the mind, to thought". 
under the droit d'auteur. ${ }^{36}$ The differing systems of protection for sound recordings (copyright in common law countries and neighbouring rights in civil law countries) have even lead to differing nomenclature, civil law countries using the term "phonograms" where common law countries use "sound recordings". ${ }^{37}$ Most importantly, the lack of protection for sound recordings under the droit d'auteur system also deprives sound recordings of the moral rights protection available under this system.

The continental position that there is insufficient creativity in a sound recording to accord its maker moral rights protection arose early in the history of the music industry. Civil law countries have often conceptualised sound recordings as nothing more than a performance being mindlessly recorded by a machine. As Marcel Plaisant, Chairman of the French Commission on Intellectual Property, put it, a sound recording was nothing but "a material instrument for the reproduction of thought", and was thus unworthy of droit d'auteur protection. ${ }^{38}$ Since machines have no human spirit, no intellectual aspect is seen as existing to which a moral right could attach. Moreover, performances (which is what the sound recording captures) have often been seen on the continent as merely an interpretation of a work that has already been created by somebody else. ${ }^{39}$ The tendency for sound recordings to be produced by bodies corporate also made it difficult to fit sound recordings into a moral rights regime because, conceptually, moral rights are exercisable by natural persons not corporations. ${ }^{40}$

Interestingly enough, English and New Zealand copyright law probably gives tacit approval to the continental approach of refusing to recognise a creative aspect to sound recordings. In the United Kingdom, a sound recording receives protection even if it is utterly devoid of originality and the author has expended "no mental skill or effort in its making". ${ }^{41}$ In New Zealand, which has an originality requirement for the subsistence of copyright in sound recordings, ${ }^{42}$ labour alone from the maker of the recording is sufficient

36 Bonnie Teller "Toward Better Protection of Performance in the United States: A Comparative Look at Performers' Rights in the United States, Under the Rome Convention and in France" (1990) 28 Colum J Transnat'l L 775, 788 .

37 Gervais, above n 10, 95.

38 Stephen M Stewart International Copyright and Neighbouring Rights (Butterworths, London, 1983) 340 .

39 Stewart, above n 38, 385.

40 Stewart, above n 38, 175.

41 Hugh Laddie, Peter Prescott and Mary Vitoria The Modern Law of Copyright and Design: Volume 1 (2 ed, Butterworths, London, 1995) 430.

42 Copyright Act 1994, ss 14(1)(b) and 14(2). 
to meet this originality requirement. ${ }^{43}$ Creativity thus plays no role in determining the subsistence of copyright in a sound recording under English and New Zealand law. The fact that the United Kingdom and the New Zealand copyright statutes do not provide for moral rights in relation to sound recordings merely underlines English and New Zealand acquiescence in the continental view that sound recordings have no creative aspect. ${ }^{44}$

This reluctance in continental and Anglo-New Zealand law to accept sound recordings as embodying a certain level of creativity can be contrasted with the United States approach to creativity in sound recordings, which the present author respectfully submits is the better approach. The United States Copyright Act 1976 recognises sound recordings as "works", 45 this choice of terminology implying that sound recordings are seen in United States jurisprudence as being imbued with some creativity. Certainly since the decision of the Supreme Court in Feist Publications Inc v Rural Telephone Service Company Inc, ${ }^{46}$ United States law requires a "modicum of creativity" before copyright protection will attach to a work. ${ }^{47}$ United States copyright law thus recognises a level of creativity in sound recordings, ${ }^{48}$ in contradistinction to the continental position, which English and New Zealand law has followed.

It is respectfully submitted that the United States approach of recognising a creative aspect in sound recordings better reflects the realities of the modern recording industry than the continental approach does. The continental view of sound recording as a purely mechanical process devoid of any creative human input may well have been true in the days when performers huddled around a gramophone and squeaked into the horn. With respect, this view of the role of creativity in sound recordings is now perversely anachronistic. As Stephen M Stewart notes, there is as just as much skill and creativity in making a sound recording as there is in adapting an orchestral score for piano. ${ }^{49}$ Since the

43 Ladbroke (Football) Ltd v William Hall (Football) Ltd [1964] 1 WLR 273, 289 (HL) per Lord Devlin: "The requirement of originality means that the product must originate with the author in the sense that it is the result of a substantial degree of skill, industry or experience employed by him" (emphasis added).

44 Copyright Act 1994, ss 94(1), 98(2) and 102(2); Copyright, Designs and Patents Act 1988 (UK), ss $77(1), 80(1)$ and $84(1)$.

45 Copyright Act 17 USC $\S \S 101,102(a)(7)(1976)$.

46 Feist Publications Inc v Rural Telephone Service Company Inc (1991) 499 US 340 [Feist].

47 Feist, above n 46, 362.

48 See Staggers v Real Authentic Sound (1999) 77 F Supp 2d 57, 61-65 (DDC), where Harris J analysed the creative contributions of the performer and the producer to determine who was the author of an "original" sound recording.

49 Stewart, above n 38, 175. 
1960s, the use of multi-track recording technology has meant that sound recordings can be polished and perfected over long periods rather than having to be recorded live. ${ }^{50}$ This quest for the "perfect sound" means that performers and their producers put considerable thought into deciding how a song should be orchestrated and recorded. Modern sound recordings thus entail not only significant labour but also a level of creativity, skill and thought.

The logical consequence of recognising the creative aspect in sound recordings should thus be a recognition of moral rights protection in relation to sound recordings. Since moral rights attach to the intellectual or mental aspect of a work, it is submitted that a sound recording should, at the threshold, normally embody enough creativity to trigger the application of the moral right. ${ }^{51}$ Admittedly, not every sound recording will have the requisite creative aspect to found moral rights protection: the mere act of switching the recorder on and making sure it is close enough to pick up a sound may well not be considered creative. ${ }^{52}$ Most sound recordings, however, and certainly all professional ones are imbued with sufficient creativity for moral rights to be logically extended to them. It is therefore submitted that New Zealand's copyright regime should be amended to provide for moral rights in relation to all sound recordings that exhibit at least a de minimis level of creativity. ${ }^{53}$

\section{Current Treatment of Sound Recordings is Anomalous}

Another reason why New Zealand's copyright regime should be amended to extend moral rights protection to sound recordings can be found in the nonsensical anomalies that exist in the current copyright regime with regard to which works receive moral rights protection and which do not. If creativity is accepted as the touchstone for moral rights protection, the New Zealand copyright regime is clearly unsatisfactory because some extraordinarily creative works, such as sound recordings, are refused moral rights protection, whereas certain mundane works without a scintilla of creativity do receive moral rights protection.

50 Michael Chanan Repeated Takes: A Short History of Recording and Its Effects on Music (Verso, London, 1995), 144.

51 J A L Sterling also submits that a sound recording should be recognised as a "phonographic work" in its own right to protect the creative contribution: J A L Sterling Intellectual Property Rights in Sound Recordings, Film and Video (Sweet \& Maxwell, London, 1992) 10 [Intellectual Property Rights in Sound Recordings, Film and Video].

52 Laddie, Prescott and Vitoria, above n 41, 431.

53 Indeed, it could be argued that a sound recording need not even be "creative" to gain moral rights protection in New Zealand: after all, no distinction is made between creative and non-creative literary works for moral rights purposes. 
The first anomaly in New Zealand's moral rights system can be found when contrasting sound recordings and musical works. A musical work receives moral rights protection but a sound recording does not. ${ }^{54}$ The anomaly here is that much of the creative work that goes into a sound recording can already be protected as a "musical work". Although traditionally musical works have been graphically represented on paper, ${ }^{55}$ they can also receive protection in New Zealand if they are fixed onto magnetic tape or some other recording device, which is precisely what happens when musicians go into a studio to make a sound recording.

In the process of interpreting a particular melody (which is a "musical work" in its own right), musicians will necessarily add their own embellishments to the basic melody in the course of the recording. Particularly if the musical work that they are performing is nothing but a melody, the musicians will need to arrange or orchestrate the recording by deciding which instruments to use and how to play them. For everything that is added to the melody, the musicians have actually made their own "musical work" because the arrangement will be "original" to the musicians. ${ }^{56}$ Since moral rights attach to "musical works", the musicians involved in making a sound recording should theoretically enjoy moral rights in the musical arrangement of a song.

By contrast, the singers involved in making the sound recording are left without moral rights protection for their vocal interpretation of the lyrics and melody. The lyrics to a song are protected as a "literary work", and the melody of a song is obviously a "musical work". ${ }^{57}$ Since singing the lyrics to the melody conceptually involves nothing more than reproducing these two already existing copyright works, the singer cannot claim to be creating any new "original work" as distinct from the melody and lyrics. Unlike the musicians, therefore, the singer cannot be considered to have created a new work and is thus denied any moral rights protection whatsoever.

This result might well be considered anomalous because the singers have put just as much skill and creativity into the recording as the musicians have, and yet the singers cannot claim a moral right in anything. When it is remembered that the skill and creativity involved in orchestrating a recording and fixing it onto tape can create both a "musical

54 Copyright Act 1994, ss 94(1), 98(2) and 102(2).

55 The Canadian Copyright Act for many years required "musical works" to be "printed, reduced to writing or otherwise graphically produced or reproduced": Copyright Act, RSC 1985, C-42, s 2 "musical work" (since amended).

56 Hugh Laddie, Peter Prescott and Mary Vitoria also submit that there is a separate copyright in the musical arrangement of a song, as distinct from the song itself and the recording: Laddie, Prescott and Vitoria, above $n$ 41, 44.

57 Copyright Act 1994, s 2 "literary work" and "musical work". 
work" and a "sound recording", it seems artificial to provide moral rights protection for this creativity as a "musical work" but not as a "sound recording". These types of nonsensical distinctions merely encourage semantic acrobatics on the part of litigants. The better approach is thus to confer moral rights on the sound recording, which would serve to protect the creativity and skill involved in the whole of the recording process and not just the creativity and skill of the musicians.

A second anomaly in New Zealand's moral rights regime can be found when comparing how moral rights attach to film soundtracks but not to sound recordings. A sound recording in itself does not attract moral rights. Yet, if a derogatory treatment of a sound recording is accompanied by the visual elements of a film, ${ }^{58}$ the director of the film has a moral right to object to a derogatory treatment of the film soundtrack. ${ }^{59}$ Music videos are the example par excellence of this anomaly, because the film soundtrack is usually identical to the sound recording that the band hopes to promote by using the music video. A sound recording thus receives moral rights protection if it is part of a film, but it receives no protection by itself. Extending moral rights to sound recordings would remove this anomaly between the treatment of sound recordings and film soundtracks under $\mathrm{New}$ Zealand's current moral rights regime.

A third and more disturbing anomaly in the New Zealand copyright regime stems from the apparent lack of thought put into the formulation of a moral rights regime for a "sweat of the brow" copyright jurisdiction such as New Zealand. ${ }^{60}$ The Copyright Act 1994 accords moral rights to categories such as literary works, which do not need any creativity to gain copyright protection, whereas the Act denies moral rights protection to sound recordings, which are decidedly creative. The nonsensical result of this drafting is that databases similar to the white pages of a telephone directory, utterly devoid of creativity, ${ }^{61}$ could qualify for moral rights protection, ${ }^{62}$ whereas a sound recording that was lovingly crafted over many months is denied moral rights protection.

58 Copyright Act 1994, s 99(4)(c).

59 Copyright Act 1994, s 99(4).

60 As noted above in Part II B, original copyright works in New Zealand need only an investment of labour from the author (the so-called "sweat of the brow" doctrine), whereas the United States requires a "modicum of creativity".

61 See Feist, above n 46, 362.

62 In reality, anonymous employees, such as the authors of the white pages, are not given moral rights: Copyright Act 1994, ss 97(6) and 100(8). However, an individual who created a similar database (for example, a customer list) would enjoy moral rights over this work, despite its lack of creativity. 
This statutory absurdity is scarcely surprising given the scant attention that New Zealand's MPs paid to the moral rights provisions of the Copyright Act 1994 as the Act went through the parliamentary process. The only mention of moral rights in the parliamentary debates during the passage of the Act was the rather superficial observation of the sponsoring Minister, the Honourable Doug Graham, that the provision of moral rights in the new Act would allow New Zealand to comply with "modern interpretations of the requirements of article 6bis of the Berne Copyright Convention". ${ }^{63}$ Indeed, Part IV of the Copyright Act 1994, which deals with moral rights, went through Parliament unopposed and without any amendments. ${ }^{64}$

This inattention to the underlying concept of moral rights has had serious and unfortunate repercussions in the current copyright regime. As Part II A of this paper outlined, moral rights are designed to protect creativity. The touchstone for copyright protection under New Zealand's "sweat of the brow" doctrine, however, is labour, with or without creativity. Grafting moral rights as an afterthought onto a "sweat of the brow" copyright system was always going to result in perverse anomalies. There is no logical reason why an individual who compiles a database should have the moral rights of paternity and of integrity in the work, but this is exactly the result that the reception of moral rights into a "sweat of the brow" copyright regime sanctions.

The present author therefore submits that the current New Zealand copyright regime lacks internal coherency due to the bizarre juxtaposition of moral rights and a "sweat of the brow" copyright regime. Part of this inconsistency would be resolved by extending moral rights to protect all creative works, including sound recordings, and the present author unhesitatingly recommends this course of action. Ideally, though, economic and moral rights should be two parallel sources of rights protecting differing aspects of the same set of works. As moral rights can conceptually protect only creative works, New Zealand may need to consider abandoning its "sweat of the brow" copyright system in favour of a system that makes creativity the touchstone for copyright protection. However, further analysis of this argument is outside the scope of this paper.

\section{Conclusion-Moral Rights Should Extend to Sound Recordings}

This Part concludes that sound recordings are imbued with sufficient creativity to qualify for moral rights protection, creativity and intellectual investment being the decisive criteria for founding this type of protection. The traditional view that sound recordings lack creativity is grossly outdated and should not be permitted to influence the contours of moral rights law any longer. The present author further argues that, in the interests of the

63 (29 November 1994) 545 NZPD 5271-5272.

64 (6 December 1994) 545 NZPD 5381. 
internal coherency of the New Zealand copyright regime, moral rights should extend to all works that show a modicum of creativity.

\section{AUTHORSHIP OF SOUND RECORDINGS AND WHO SHOULD EXERCISE THE MORAL RIGHTS IN A SOUND RECORDING}

The first issue to consider in determining how to extend moral rights to sound recordings is who should exercise these rights over the sound recording. In particular, this Part examines waivers and work-for-hire works, and argues that sound engineers and producers, as well as performers, should be allowed to exercise the moral rights over a sound recording.

\section{A Concept of Authorship and the Moral Right}

In determining who should exercise moral rights over a sound recording, it is necessary first to look at the relationship between authors and moral rights. Conceptually, moral rights protect authors' creative and intellectual investment in their work. In New Zealand's copyright regime, the moral right generally attaches to the "author", who is defined in section 5(1) as the person who "creates" the work. For works that are created by natural persons, such as literary, dramatic, musical or artistic works, the moral right is exercisable by these natural persons. ${ }^{65}$ For films, the moral right vests in the director, ${ }^{66}$ even though the economic rights vest in the person "by whom the arrangements necessary for the making of the recording or film are undertaken", ${ }^{67}$ which is normally a body corporate. The moral right thus attaches to the natural persons who imbue the work with its creativity, and this principle must inform the discussion on who should exercise any potential moral right in a sound recording.

Following this logic, one would expect that the moral rights over a sound recording should attach to those who put the creative energy into the recording itself. Article 5(1) of the Treaty requires that the moral right over a sound recording should vest in the "performers". "Performers" are defined in article 2(a) of the Treaty as "actors, singers, musicians, dancers, and other persons who act, sing, deliver, declaim, play in, interpret, or otherwise perform literary works". ${ }^{68}$ Moral rights, then, should extend at least to the singers and musicians who perform on the sound recording.

65 Copyright Act 1994, ss 5(2)(a), 94(1)(a) and 98(2)(a).

66 Copyright Act 1994, ss 94(1)(b) and 98(2)(b).

67 Copyright Act 1994, s 5(2)(b).

68 "Literary works" here includes "musical works". 


\section{B Who Should Exercise the Moral Right in a Polyvocal Work?}

However, when one considers who should exercise the moral rights over a sound recording, certain problems arise that do not arise with other categories of work. One problem in extending moral rights to a sound recording is the polyvocal nature of sound recordings. Normally, any number of people has collaborated on the recording-singers, musicians, sound engineers and a producer. For films, which also involve contributions from many people, the director alone has been vested with the moral rights over the film in New Zealand. ${ }^{69}$ This regime, however, may be inappropriate for sound recordings.

Probably, the best solution is to allow each individual who has contributed to the sound recording to exercise moral rights over the work. Certainly, this solution would be consistent with the principle that moral rights protect the creative investment of the authors. French law, for example, has no problem in nominating five authors for a film, and all of them would appear to be able to exercise moral rights under French law. ${ }^{70}$ Having multiple persons able to exercise moral rights over one work is not unknown to New Zealand law either, as the current copyright regime already contemplates this approach in the joint authorship provisions.

With "works of joint authorship", in which each author's contribution is not distinct from that of the others, ${ }^{71}$ each author may exercise the moral rights over the work independently of the other authors. ${ }^{72}$ Similarly, it is often difficult to distil each individual's particular contribution to a sound recording; even if the singer's voice can be distinguished from the guitarist's strumming, it is usually impossible to tell exactly who has contributed what to the recording. Thus, the better solution would be to permit all those involved in making the sound recording to exercise moral rights over their respective contributions. Such a regime would be analogous to the joint authorship provisions and thus need not offend against the internal coherency of the Copyright Act.

Additionally, New Zealand could provide for a regime as in Slovenia where a group of performers can nominate a member of their group to exercise the moral rights on the

69 Copyright Act 1994, ss 94(1)(b) and 98(2)(b).

70 French Intellectual Property Code 1992, art L 113-7. Absent proof to the contrary, the author of the plot, the person adapting it for film, the person who writes the screenplay, the author of musical compositions written for the film and the director are all considered co-authors of the film. Authors of any pre-existing works from which the film has been based are assimilated into the authorship of the film.

71 Copyright Act 1994, s 6(1).

72 Copyright Act 1994, s 6(3). Waiver of moral rights by one author does not affect the other authors' rights: Copyright Act 1994, ss 108 and 109. 
group's behalf. ${ }^{73}$ The representative acts on the vote of a majority of the group. ${ }^{74}$ This regime could provide a useful alternative where a band is more concerned with its group identity.

Some commentators argue that it would be undesirable to give the moral rights over sound recordings to numerous people because a single collaborator could then exercise the moral rights over the work, thereby preventing the dissemination of copyright works to the public. ${ }^{75}$ In reality, this result need not be so. The moral rights of paternity and integrity are subject to particular limitations under New Zealand law, which should alleviate these sorts of problems. In addition, injunctions are not the only remedies available for breach of moral rights. Parts IV and V of this paper will deal further with the exact contours of these moral rights and with the remedies available for their breach. For now, it will suffice to note that giving the moral rights over a sound recording to numerous people need not in itself result in undesirable consequences.

One final problem is the status of sound engineers and producers, who do not fall within the Treaty definition of "performers", even though they often make significant contributions to the creative aspect of the sound recording. For example, Michael Chanan believes that George Martin's creative input as producer of the Beatles was so great that he could be said to have directed the Beatles "not so much like a conductor in front of an orchestra, but as if they were making a film". ${ }^{76}$ Interestingly, Slovenian law treats sound editors as "performers" for the purposes of its performers' rights provisions. ${ }^{77}$ Since the purpose of moral rights is to protect creative input, the present author argues that moral rights in New Zealand law should be extended to allow sound engineers and producers to exercise moral rights where they can show that they have contributed creatively to the recording.

\section{Moral and Economic Rights in Sound Recordings Necessarily Vest in Separate Entities}

A further quirk to note is that the authorship of a sound recording normally vests not with the persons who create the recording but with the person who makes the arrangements for the recording. ${ }^{78}$ The result is that the record company and not the

\footnotetext{
73 Copyright and Related Rights Act 1995 (Slovenia), art 119.

74 Copyright and Related Rights Act 1995 (Slovenia), art 119(2).

75 See Robert A Gorman "Federal Moral Rights Legislation: the Need for Caution" (1990) 14 Nova L Rev 421, 423-424

76 Chanan, above n 50, 143-144.

77 Copyright and Related Rights Act 1995 (Slovenia), art 118(2).

78 Copyright Act 1994, s 5(2)(b)
} 
performers normally own the copyright in a sound recording. Given that the author of the sound recording is thus normally a body corporate, ${ }^{79}$ would it be appropriate for moral rights to attach to the author as normally occurs?

Since moral rights protect authors' intellectual links with their works, these rights cannot logically be exercisable by bodies corporate. ${ }^{80}$ Yet, the treatment of films under the moral rights regime shows that it is possible to allow a natural person involved in creating the work to exercise moral rights over it, even though the work's "author" (as defined in section 5) is a body corporate. The "author" of a film is defined as the "person by whom the arrangements necessary for the making of...the film are undertaken", 81 and this is normally a body corporate. The moral rights, however, are exercisable by a natural person, the director, who has overall artistic and creative control of the film. ${ }^{82}$ It would thus be consistent with the current copyright regime for the moral rights over sound recordings to vest in those making the creative input, namely the performers, engineers and producers, rather than the record company. ${ }^{83}$ In any event, since most authors usually transfer the copyright in their works, separate ownership of the economic and moral rights is not a problem specific to sound recordings.

\section{Work-for-hire Problems-What Happens When the Performers are Employees?}

Certain problems arise when the performers trying to exercise their moral rights are also employees of the producing record company, which is often the case for the backing musicians. Employees are afforded very little moral rights protection under the Copyright Act $1994 .{ }^{84}$ However, since the employment status of the performer generally affects the remedies available for breach of the moral right rather than the contours of the right itself, further discussion is postponed until Part V of this paper. ${ }^{85}$ The point to note is that the

79 The Act expressly contemplates that bodies corporate may be "authors": Copyright Act 1994, s $5(3)$.

80

Stewart, above n $38,175$.

81 Copyright Act 1994, s 5(2)(b).

82 Copyright Act 1994, ss 94(1)(b), 98(2)(b) and 102(2)(b).

83 Admittedly, the suggested moral rights regime for sound recordings is not fully consistent with that for films, in that only one person (the director) can exercise moral rights over the film, yet numerous people are likely to exercise moral rights over sound recordings. The difference probably results from the fact society tends to attribute films to their directors, yet perceives performers as the "stars" of sound recordings.

84 Raewyn Tate (ed) Intellectual Property in New Zealand: Copyright and Design (Butterworths, Wellington, 1996) para S100.6 (updated June 1996).

85 Copyright Act 1994, ss 97(6), 100(8), 100(9), 101(4) and 101(5). 
employment status of performers in itself need not prevent them from enjoying moral rights under the New Zealand copyright regime as it is currently drafted.

\section{E Waiver of Moral Rights in Sound Recordings}

One feature of the New Zealand copyright regime that could frustrate implementation of article 5(1) of the Treaty is the fact that moral rights can be waived. ${ }^{86}$ Such waivers are becoming standard clauses in industry contracts, particularly with sound recordings and films. ${ }^{87}$ It could thus be argued that enacting moral rights in respect of sound recordings would be otiose, given these standard-form waivers. However, enacting a moral right for sound recordings might still be beneficial for performers.

First, a waiver of moral rights can extend only to the copyright owner and future licensees. ${ }^{88}$ In this way, performers could immunise their record company and future licensees from moral rights suit but would benefit from being able to sue third parties who mistreated their work. Secondly, even if those in weak bargaining positions are pressured to waive their moral rights, ${ }^{89}$ a performer with sufficient clout to limit or to resist a waiver would benefit from any enacted moral rights provisions. Standard-form waivers may be a problem for many performers, but this problem exists within all categories of copyright work, and is thus not a valid reason for specifically excluding the performers of sound recordings from the scope of moral rights protection.

\section{F Conclusion}

Some problems may arise in bringing sound recordings within the moral rights regime in New Zealand, due to the polyvocal nature of sound recordings. However, the current copyright regime already contemplates the exercise of moral rights by multiple authors. Thus, sound recordings should not create any new problems in this respect. One adaptation of the moral rights regime that could usefully be suggested in respect of sound recordings is for performers to have the right to nominate a representative to exercise their moral rights. Apart from this, the current scheme of the Copyright Act should allow performers, sound engineers and producers to exercise moral rights over sound recordings without the internal consistency of the copyright regime being significantly disturbed.

86 Copyright Act 1994, s 107

87 Tate, above n 84, para S107.5 (updated June 1996).

88 Copyright Act 1994, s 107(2)(d).

89 Tate, above n 84, para S107.5 (updated June 1996). 


\section{THE VARIOUS MORAL RIGHTS AS THEY RELATE TO SOUND RECORDINGS}

The second issue to consider in determining how to extend moral rights to sound recordings is how moral rights would work in practice in the recording industry. In particular, this Part examines certain commonplace activities in the music industry such as re-mastering, re-mixing and sampling, and observes that these practices could be affected if a moral rights regime were introduced to protect the performers, sound engineers and producers of sound recordings.

\section{A The Right of Paternity}

\section{Introduction}

The first moral right that this paper will consider is the moral right of paternity. ${ }^{90}$ This right allows the author of a work to claim the authorship of that work. The right of paternity is an important right because whoever is recognised as the author of a work is the only person who can exercise the more powerful moral right of integrity. ${ }^{91}$ A classic example of an action to enforce the right of paternity is the Canadian case Boudreau $v$ Lin and others, where a university professor published a student's work, removing the student's name from the paper and adding his own as author. ${ }^{92}$ The student won $\$ 7,500$ in damages against the professor for breaching his right of paternity.

In New Zealand law, this right does not arise automatically. The right of paternity cannot be breached unless the author has first "asserted" it, a limitation that Professor Gerald Dworkin describes as "very controversial". 93 This assertion can be made by instrument in writing or by a statement of assertion in the assignment of copyright. ${ }^{94} \mathrm{In}$ effect, the assertion is a statement that the author wishes to be named on all copies of the work. ${ }^{95}$ A further limitation is that the right does not attach to works made in the course of employment unless the individual employee who created the work is readily identifiable. ${ }^{96}$

90 Copyright Act 1994, ss 94-97.

91 Moral rights cannot be assigned but can be left by testamentary disposition: Copyright Act 1994, ss $118-119$.

92 Boudreau v Lin and others (1997) 75 CPR (3d) 1 (Ont Ct (Gen Div)).

93 Gerald Dworkin "The Moral Right of the Author: Moral Rights and the Common Law Countries" (1995) 19 Colum-VLA JL \& Arts 229, 248.

Copyright Act 1994, s 96(2).

95 Tate, above n 84, para S96.4 (updated June 1996).

96 Copyright Act 1994, s 97(6). 


\section{Concerns over extending the right of paternity to sound recordings}

In general, extending the right of paternity to sound recordings would thus require the identification of the performers (and possibly the producer and sound engineers) of a sound recording whenever their sound recording was sold or broadcast. However, as many commentators argue, extending the right of paternity to sound recordings could become unwieldy in practice, because it would be impractical to require all the performers, producers and engineers of a sound recording to be listed every time it was sold or played. ${ }^{97}$ Arthur B Sackler particularly attacks the right of paternity as it would apply to music broadcast on radio, warning that the right would lead to an "enormous encroachment on available airtime" that would "impede programming and, at a minimum, irritate listeners". ${ }^{98}$

These concerns are understandable, but the present author argues that the wording of article 5(1) of the Treaty should allay these concerns. Article 5(1) limits the circumstances in which the right to paternity arises for performers, providing for a performer's right to claim to be identified as the performer, "...except where omission is dictated by the manner of the use of the performance". In effect, this wide proviso should alleviate most problems. Furthermore, the Copyright Act 1994 adds other limits to the right of paternity that would further mitigate the worst excesses of extending the right of paternity to sound recordings.

\section{The right of paternity and the commercial exploitation of sound recordings}

Generally, a sound recording can be commercially exploited in two ways: it can be sold (or hired) to the public on a CD or other sound carrier, or it can be broadcast to the public. Applying the moral right of paternity to selling sound recordings would scarcely entail any changes from standard music industry practice, because it is already normal for performers to be credited somewhere on the CD box. ${ }^{99}$ Indeed, the performers' names are often the biggest marketing tool that the music industry has. ${ }^{100}$

In respect of the broadcast of sound recordings, the proviso in article 5(1) sanctioning omission of the right of paternity where it is "dictated by the manner of the use of the

97 Professor Robert A Gorman notes the extreme example of a Brazilian court that ordered radio stations to name all composers, lyricists and performers of all broadcast music: Gorman, above $n$ 75,426 .

98 Arthur B Sackler "The United States Should Not Adhere to the Berne Copyright Convention" (1987) 3 JL \& Tech 207, 208.

99 This practice is sufficient acknowledgement: Copyright Act 1994, s 95(1)(a)(i).

100 John M Kernochan "Moral Rights_Practical Perspectives" (1989) 14 Colum-VLA JL \& Arts 25, 71. 
performance" is important to note. It would often be impractical for radio stations to name the performers of the sound recordings that they broadcast, and indeed, radio stations are currently exempted from having to name the songwriter whenever recordings of that songwriter's songs are broadcast. ${ }^{101}$ The broadcast of sound recordings is probably, then, a "manner of use" that should dictate omission of the right of paternity, and ratification of the Treaty should not entail major burdens on broadcasters.

It is interesting to note, however, that until the 1950s, it was the practice for New Zealand radio stations to mention the record company whenever a sound recording was broadcast. ${ }^{102}$ Indeed, State-owned Radio New Zealand still names composers, performers and sometimes even record labels on its Concert FM network. ${ }^{103}$ In reality, though, commercial radio stations frequently omit the performers of sound recordings they play, because these stations assume that their listeners will know the performers and the names of the songs that are regularly broadcast. Thus, the "manner of use" proviso to article 5(1) should probably permit omission of the right of paternity at least for commercial broadcasting purposes.

Even when a radio station decides to name the main performers of a sound recording, the nature of broadcasting would make it impractical for stations to broadcast every backing musician, sound engineer and producer of a sound recording every time that sound recording is broadcast. The proviso in article 5(1) of the Treaty would thus sanction omission of these contributors' names. Furthermore, where the performers created the work during the course of employment, they are not entitled to the right of paternity, unless they have asserted the right and can be reasonably identified. ${ }^{104}$ If the minor contributors are employees unnamed on the sound recording, their right of paternity is extinguished.

Under closer analysis, fears of unwieldy complications from extending the right of paternity to the performers of sound recordings are in reality largely unfounded and alarmist. Enactment of this right in New Zealand law would thus entail few, if any, changes to the way that sound recordings are currently accredited.

101 Copyright Act 1994, s 94(4).

102 Bruce Anderson Story of the New Zealand Record Industry (Bruce Anderson, Wellington, 1984) 57. Bruce Anderson actually claims that this was "required by law", although the present author found no such requirement in either the Copyright Act 1913 or the Broadcasting Act 1936, the relevant legislation at the time. Most probably, this was mere policy on the part of the National Broadcasting Service.

103 Record labels and serial numbers are given on Concert FM's "Classical Chart" programme broadcast on Saturday afternoons.

104 Copyright Act 1994, ss 96 and 97(6). 


\section{The right against false attribution}

In addition to the right of paternity, the Copyright Act 1994 also provides redress for people who have wrongly been identified as the author of a work and who wish to distance themselves from the work. ${ }^{105}$ If moral rights were to be extended to sound recordings, this section should logically be amended to allow people to dissociate themselves from sound recordings with which they have been erroneously associated.

\section{B The Right of Integrity}

\section{What are the parameters of the right of integrity?}

The other moral right recognised in New Zealand law is the right of integrity. ${ }^{106}$ From the outset, it should be noted that the right of integrity is the very right against which most anti-moral rights commentators complain. They argue that this right upsets the innovation incentive of copyright law because it allows authors to prevent others from adapting their work. ${ }^{107}$ The exact scope of this right in New Zealand is uncertain because no New Zealand court has yet had to deal with it.

Before analysing how the right of integrity would affect sound recordings, it is first necessary to outline the parameters of the right. The authors of literary, artistic, musical and dramatic works (as well as the directors of films) have a right not to have their works subjected to a "derogatory treatment". ${ }^{108}$ A "treatment" is defined as "any addition to, deletion from, alteration to, or adaptation of the work" but excludes translations and changes of key in musical works. ${ }^{109}$ The treatment is "derogatory" if "...whether by distortion or mutilation of the work or otherwise, the treatment is prejudicial to the honour or reputation of the author or director". ${ }^{110}$

Essentially, there is a two-tier test for showing a breach of the right of integrity: the work must have been given a "treatment" that is "derogatory". ${ }^{111}$ Thus, the two issues that need consideration in applying the right of integrity to sound recordings are, first, what

\footnotetext{
105 Copyright Act 1994, s 102.

106 Copyright Act 1994, ss 98-101.

107 A particularly virulent attack on moral rights for its impeding of innovation can be found in Lawrence Adam Beyer "Intentionalism, Art, and the Suppression of Innovation: Film Colorization and the Philosophy of Moral Rights" (1988) 82 NWUL Rev 1011.

108 Copyright Act 1994, s 98.

109 Copyright Act 1994, s 98(1)(a)

110 Copyright Act 1994, s 98(1)(b).

111 Tate, above n 84, para S98.3 (updated February 1998).
} 
counts as a "treatment" of a sound recording and, secondly, how to determine whether a treatment is "prejudicial to the honour and reputation" of the creators of a sound recording.

In respect of the "treatment" of a sound recording, it must be remembered that copyright (and thus the moral right) protects intellectual property, not the physical embodiment of that property. ${ }^{112}$ Normally, of course, when imagining a derogatory "treatment" of a work, what comes to mind is the defacing of a painting. Obviously, with a painting, the intellectual property and the physical embodiment of that property are inseparably bound in the canvas, so defacing the canvas automatically involves a "treatment" of the work.

With a sound recording, however, the actual work, which is the recorded performance as detected by the senses, is separately distinct from the tape on which it is recorded or the copies of the CD that reproduce the recording. Defacing the physical embodiment of the recorded performance is thus not a "treatment" of the sound recording. Rather, a "treatment" of the sound recording is anything that changes the way the sound recording is detected by the senses. Thus, in Schott Musik International GmbH \& Co and others $v$ Colossal Records of Australia Pty Ltd and others, Lindgren J held that a "musical work" was "debased", within the meaning of section 55(2) of the Copyright Act 1968 (Cth), when it had undergone a change in the "arrangement of the 'sounds and noises"'. ${ }^{113}$ By analogy, then, a "treatment" of a sound recording would occur when it undergoes a change in its "sounds and noises".

As for determining what constitutes a "derogatory" treatment of a work, the problem is how to interpret the phrase "prejudicial to the honour or reputation of the author or director". ${ }^{114}$ As Professor Gerald Dworkin notes, how this phrase is interpreted will turn on "whether the court takes an objective or subjective view of what is prejudicial to the author". 115 The "subjective" standard involves accepting the artist's evidence of prejudice, whereas the "objective" standard involves some form of expert opinion on whether the treatment would lower the artist's "honour or reputation". Unfortunately, the overseas case law is divided over whether a subjective or an objective standard should apply.

112 However, the Copyright Act 1976 (US) also extends copyright protection to the physical medium in which a sound recording is first fixed: 17 USC $§ 101$ "phonorecord".

113 Schott Musik International GmbH \& Co and others v Colossal Records of Australia Pty Ltd and others (1997) 145 ALR 483, 497 (FCA) per Lindgren J [Schott Musik(Full Court)].

114 Copyright Act 1994, s 98(1)(b).

115 Dworkin, above 93, 251. 
The first Canadian case to rule on the issue, Snow $v$ Eaton Centre Ltd, ${ }^{116}$ applied a subjective standard. In that case, a sculptor won an injunction to have red ribbon Christmas decorations removed from his sculpture of flying geese on the ground that this constituted a "derogatory treatment". In his judgment, O'Brien J said that the words "prejudicial to his honour and reputation" in section 12(7) of the Canadian Copyright Act (since amended) involved "a certain subjective element or judgment on the part of the author so long as it is reasonably arrived at". ${ }^{117}$

The legislative history of the United Kingdom's moral rights provisions also supports the use of a subjective standard. When the United Kingdom passed its right of integrity, ${ }^{118}$ a proposal for a reasonableness requirement in the author's use of the right (which would, in effect, create an objective standard) was consciously rejected on the ground that the Berne Copyright Convention, which embodied the traditional subjective standard of French law, ${ }^{119}$ did not impose any such restriction on the right of integrity. ${ }^{120}$ Furthermore, courts have always been careful "not to impose on the rest of society the artistic or aesthetic tastes of an individual judge or group of judges". ${ }^{121}$ Accepting a certain subjective judgment on the part of the author in a moral rights action thus saves judges from having to assume the role of arbiters of taste.

However, precedent also exists for the opposite view that an objective standard should apply in determining "prejudice to the author's honour or reputation". In one of the United Kingdom's few moral rights cases, Morritt J appeared to support an objective standard in an interlocutory proceeding where George Michael alleged his moral rights as a songwriter had been breached when the defendants made a "mega-mix" involving excerpts from five of his songs. Morritt J placed weight on the evidence of professional songwriters and disk jockeys for both sides, thus suggesting a need for some objective determination of prejudice to the author's honour or reputation. ${ }^{122}$

116 Snow v Eaton Centre Ltd (1982) 70 CPR (2d) 105 (Ont HC) [Snow].

117 Snow, above n 116, 106.

118 Copyright, Designs and Patents Act 1988 (UK), s 80. The New Zealand provision is identically worded: Copyright Act 1994, s 98.

119 Alfred Dietz "The Moral Right of the Author: Moral Rights and the Civil Law Countries" (1995) 19 Colum-VLA JL \& Arts 199, 222.

120 Dworkin, above n 93, 252.

121 Schott Musik International GmbH \& Co and others v Colossal Records of Australia Pty Ltd and others (1996) 141 ALR 433, 438 (FCA) per Tamberlin J [Schott Musik (Trial FCA)].

122 Morrison Leahy Music Ltd v Lightbond Ltd [1993] EMLR 144 (Ch) [Morrison Leahy]. 
Furthermore, Canadian cases after Snow seem to require some objective evidence of injury to the author's honour or reputation. In Pollock $v$ CFCN Productions Ltd and others, Moore ACJ used affidavits from expert playwrights to grant an interlocutory injunction to prevent use of a screenplay that was arguably a derogatory treatment of the plaintiff's original play. ${ }^{123}$ In Prise de Parole Inc v Guerin, ${ }^{124}$ an author complained that the clumsy manner in which his short story had been adapted for inclusion in an anthology for school students breached his moral right of integrity. Denault $J$ refused the injunction, holding that the breach of the right of integrity required an "objective evaluation of the prejudice based on public or expert opinion", and this the plaintiff had failed to show. ${ }^{125}$ Indeed, Denault $\mathrm{J}$ noted that the applicant in Snow had satisfied this objective evaluation by adducing evidence showing that his belief in prejudice to his reputation was "shared by a number of other well respected artists and people knowledgeable in his field". ${ }^{126}$

Although Australia has not yet enacted a moral rights regime, section 55(2) of the Copyright Act 1968 (Cth) provides a right similar to the right of integrity specifically in relation to musical works. Section 55 establishes a compulsory licence scheme whereby anyone, upon payment of a levy, may record any musical work, provided that the recording does not "debase the original work". This provision was recently interpreted in Schott Musik, where the issue was whether a "techno" version of Carl Orff's "Carmina Burana" had "debased" the original work. The judges in the case all used varying objective standards to determine what "debased" meant. Hill J asked whether a "reasonable person will be led to think less of the original work", ${ }^{127}$ whereas Wilcox and Lindgren JJ approved of a broad comparison between the adaptation and the original work. ${ }^{128}$

In principle, it would appear better if the author, whose reputation is to be affected, could decide what has harmed his or her reputation and what has not-after all, only the author knows what sort of reputation he or she wants. Pragmatically, however, the potentially indeterminate nature of a subjective test is unpalatable, because a subjective test might give authors too much power to stop others using their works. To minimise this

123 Pollock v CFCN Productions Ltd and others (1983) 73 CPR (2d) 204 (Alb QB).

124 Prise de Parole v Guerin (1995) 66 CPR (3d) 257 (Can Fed TD) [Guerin (Can Fed TD)]. This case was appealed but the appeal went only to quantum: Prise de Parole v Guerin (1996) 73 CPR (3d) 557 (Can Fed CA).

125 Guerin (Can Fed TD), above n 124, 265.

126 Snow, above n 116, 106.

127 Schott Musik(Full FCA), above n 113, 493 per Hill J.

128 Schott Music (Full FCA), above n 113, 498 per Lindgren J; Schott Musik (Full FCA), above n 113, 485 per Wilcox J. 
risk, the writers of Intellectual Property in New Zealand: Copyright and Design suggest that the right of integrity should require an objective standard in finding prejudice to the author's reputation. ${ }^{129}$

The present author, however, submits that some form of subjective standard is more appropriate for determining when a treatment has been "derogatory". It seems doubtful that a wholly objective standard was ever intended: this would do nothing more than replicate the tort of defamation, and moral rights were enacted precisely because defamation was seen as insufficient in protecting authors' rights in this area. In Schott Musik, the trial judge, Tamberlin J, observed that these types of exercises are neither wholly objective nor wholly subjective. ${ }^{130}$ The present author thus submits that New Zealand should adopt a hybrid test as in Snow, with a court willing to accept an author's claim of prejudice provided it is backed with some form of expert opinion.

\section{Application of the right of integrity to sound recordings}

The preceding discussion over whether to use a subjective or an objective standard in determining what is "derogatory" is important in the context of extending moral rights to sound recordings. Clearly, if some form of subjective standard is used, it becomes easier for performers, engineers or producers to object to "treatments" of their sound recordings. The right of integrity could thus have a significant impact on the music industry, because a number of standard practices in the industry, such as digital re-mastering, re-mixing, and sampling, clearly involve a "treatment" of a sound recording. The issue becomes more pressing in respect of sound recordings because the same technological advances that allow perfect digital copies to be made of sound recordings also allow those same recordings to be easily altered. ${ }^{131}$

Digital re-mastering is a process where older recordings made on analogue equipment (such as magnetic tape) are transferred to a computerised "digital" format. During this process, re-mastering can delete unwanted noises from the old recording (such as hiss or clicks on a record), enhance the sound to make it clearer, and even allow new sounds to be inserted into the recording. ${ }^{132}$ Obviously, this process involves a "treatment" of the original sound recording, but since it normally involves the enhancement of sound quality, the

129 Tate, above n 84, para S98.3 (updated February 1998).

130 Schott Musik (Trial FCA), above n 121, 438.

131 On digital copying see generally Dean S Marks and Bruce H Turnball Technical Protection Measures: The Intersection of Technology, Law and Commercial Licenses: WCT-WPPT/IMP/3 (World Intellectual Property Organisation, Geneva, 1999) 2.

132 Intellectual Property Rights in Sound Recordings, above n 51, 78. 
introduction of moral rights over sound recordings is unlikely to allow performers or engineers to object to the re-mastering of their work.

Re-mixing is another process that could potentially trigger the moral right of integrity in respect of sound recordings, but a brief description of how sound recordings are made is needed to make sense of this process. When the musicians are recording in the studio, each voice and instrument is recorded separately with its own microphone onto its own tape (or "track"), thus permitting each element of the sound to be isolated. After the actual recording session, the tracks are "mixed" together to create an overall balance among the various components. Isolating each instrument onto separate tracks means that tracks can be removed or new ones added if different instruments are ultimately preferred on the recording (say a piano rather than an electric guitar). The final "master" mix is then released. ${ }^{133}$

Re-mixing occurs when this supposedly final "mix" is altered, by adding in new sounds, deleting old ones or adjusting the balance among the tracks. Re-mixes are becoming increasingly common in the music industry, where "mastering different versions of the mix for different media" is quite normal and "the final mix is often not the final product". ${ }^{134}$ Re-mixing would certainly constitute a "treatment" of the original sound recording because the way it sounds is being "altered". ${ }^{135}$ In one French case, the Court of First Instance of Paris found that a conductor's moral right of integrity had been breached when his recording of an opera was used in a film soundtrack that superimposed onto it various sounds from the film, including spitting, urination and female panting. ${ }^{136}$ Thus, any alteration to the way a sound recording sounds could potentially trigger a breach of the right of integrity.

Analogous to re-mixing is the practice of sampling. Here, rather than altering the arrangements in somebody else's sound recording, samplers take a small snippet of a sound recording and use it in their own recording, often digitally altering the sound. ${ }^{137}$ Following Morrison Leahy, ${ }^{138}$ where making a medley out of snippets from five George Michael recordings was held to be a "treatment" of the underlying "musical works", it

133 See Chanan, above n 50, 144

134 Chanan, above n 50, 148.

135 Copyright Act 1994, s 98(1)(a).

136 Rostropovitch v Sté Erato Disques and others (1990) 145 RIDA 368 (Trib Gr Inst, Paris, 1 Ch, 10 January 1990) [Rostropovitch].

137 Intellectual Property Rights in Sound Recordings, above n 51, 78.

138 Morrison Leahy, above n 122. 
would appear that any such editing would also constitute a "treatment" of the sound recordings. Even if the sample lasts for only a second, this would be a treatment. ${ }^{139}$ In practice, though, sampling will often not be actionable. If the sampled sounds were altered beyond recognition, as often occurs with sampling, ${ }^{140}$ the performers' honour and reputation could never be prejudiced because it would be impossible to identify which recording had been sampled. Nevertheless, the introduction of moral rights over sound recordings might well in some cases allow the performers, sound engineers or producers of sound recordings to prevent them from being sampled in later recordings.

\section{Conclusion}

The introduction into New Zealand law of moral rights for the performers, sound engineers and producers of sound recordings will create significant practical difficulties for the music industry that need to be overcome. Particularly, the practices of re-mixing and sampling (and, to a lesser extent, re-mastering) may become more limited in their application, but precisely how limited they become will depend on whether a subjective or an objective determination of "prejudice to honour or reputation" is taken in New Zealand. Admittedly, a more subjective standard, as argued for in this paper, gives performers, sound engineers and producers greater scope for arguing that a re-mixing, sampling or remastering of their sound recording has breached the moral right.

The impact on the music industry, however, need not be as detrimental as some fear. First, and as is implicit in the foregoing discussion, there is no infringement if the relevant party has consented to the treatment. ${ }^{141}$ Furthermore, there is no requirement that this consent be in writing and it may be express or implied. ${ }^{142}$ Secondly, even if breach of the right of integrity is made out, an injunction to remove the offending sound recording from circulation need not follow automatically as the remedy. The question of what relief should be available for a breach of moral rights is discussed in Part V of this paper.

Other problems arising from extending the right of integrity to sound recordings might usefully be combated by bringing sound recordings within the regime that governs films under the Copyright Act 1994. For example, deletions to films to comply with broadcasting schedules are permitted, and a similar right might be needed to allow radio stations to end

139 Unlike an action for infringement of copyright, the moral right to object to a derogatory treatment can apply in respect of any part of a work, even if not a "substantial part" of the work: Copyright Act 1994, s 110(2)(a).

140 Steve Jones "Music and Copyright in the USA" in Simon Frith (ed) Music and Copyright (Edinburgh University Press, Edinburgh, 1993) 76.

141 Copyright Act 1994, s 107(1).

142 Tate, above n 84, para S107.3 (updated June 1996). 
a song early to play the news or move to another programme. ${ }^{143}$ In addition, excerpts from films can be used to advertise the film without breaching the right of integrity, ${ }^{144}$ and a similar right in respect of sound recordings would be useful. French law has found a breach of two songwriters' moral rights when an excerpt of a recording of their composition was included in a television commercial advertising a CD that included their song. ${ }^{145}$ Such extreme results could be alleviated in New Zealand by modelling any new right of integrity as regards sound recordings on the existing provisions for the right of integrity in films.

\section{The Right of Divulgation}

Only the moral rights of paternity and integrity are recognised under New Zealand law and in article 5(1) of the Treaty. However, civil law countries also recognise a right of divulgation, which "reserves to the author the fundamental decision whether at all and when and how to release his work from the private sphere and to expose it to the public". ${ }^{146}$ This right could be particularly important in respect of sound recordings. Usually, numerous versions or "mixes" of a sound recording are made before a final version is selected for release, but these rejected versions are never intended for publication. However, as in the example of the Little River Band given in Part I of this paper, record companies sometimes release these rejected versions against the performers' wishes. No breach of the right of integrity could lie for publishing these re-mixes because the performers themselves made the rejected versions. Consequently, article 5(1) of the Treaty would leave performers such as the Little River Band without redress when their imperfect recordings were released to the public without their consent. A right of divulgation in the case of sound recordings thus becomes attractive.

However, it might be possible to deal with the release of these imperfect recordings as a breach of the right of integrity, rather than by creating a whole new right of divulgation. French law provides that a film author's moral right can be asserted only when the final version of the film has been established. ${ }^{147}$ Thus, releasing alternative working versions of the film count as a breach of the right of integrity, because the way the "definitive" version of the film looks has been altered. New Zealand could adopt a similar regime, where the right of integrity would protect the "definitive" version of a sound recording. Releasing

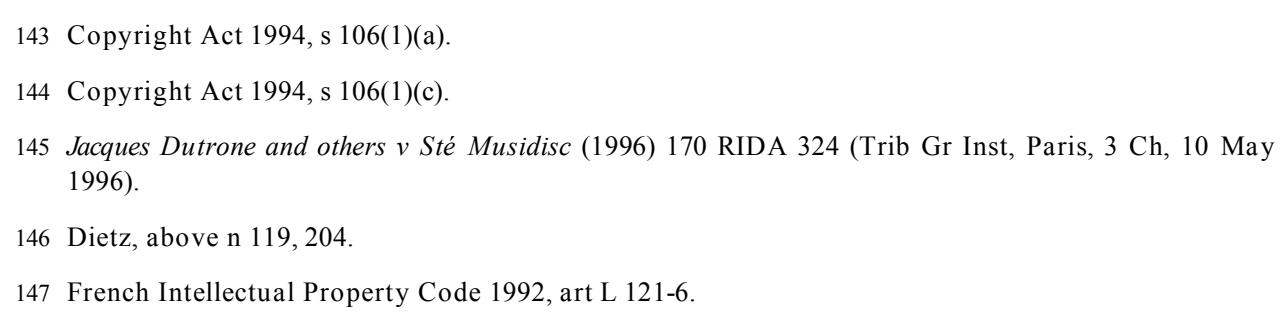


other versions of the recording without the performers' consent (whether they are made after or predate the "definitive" version) could then be held to breach the right of integrity, even if the performers themselves had originally fixed that version.

\section{Conclusion}

Extending the right of paternity to sound recordings is unlikely to result in any changes to current music practice as regards naming performers and sound engineers on CDs. Broadcasters are also unlikely to be unduly burdened by a right of paternity over sound recordings. The right of integrity, however, might affect the practices of re-mixing and sampling of sound recordings, and this impact would be greater if a subjective standard were applied in determining whether a treatment was "derogatory".

\section{REMEDIES}

The third issue to consider in determining how to extend moral rights to sound recordings is what remedies to give for a breach of these rights. This Part outlines the remedies currently available for breach of moral rights under New Zealand law and argues that the current provisions can be extended to breaches of moral rights over sound recordings without causing widespread disruption to the music industry, as some commentators fear.

\section{A Remedies Available}

Andrew Brown and Julien Miles QC note that breach of an author's moral rights results in a right of action accruing to the person entitled to the moral right. ${ }^{148}$ Section $125(2)$ of the Copyright Act 1994 provides that relief by way of damages or injunction is available. Laddie, Prescott and Vitoria submit that damages could include compensation for injured feelings. ${ }^{149}$ The present author submits that exemplary damages might also be available as a remedy. Certainly, section 125 does not preclude an award of exemplary damages for breaches of moral rights. However, criminal proceedings do not lie in New Zealand for breaches of the moral right, in contradistinction to the position under French law, which probably considers such conduct as a misdemeanour. ${ }^{150}$

When the right of integrity has been breached, section 125(3) gives courts the alternative remedy of ordering a disclaimer to be made "dissociating the author or director

148 Andrew Brown and Julien Miles Update on Intellectual Property Reforms (New Zealand Law Society, Wellington, 1995) 27.

149 Laddie, Prescott and Vitoria, above n 41, 1030.

150 Frédéric Pollaud-Dulian "Le Droit moral en France: à travers la jurisprudence récente" (1990) 145 RIDA 126,151 . French case law has held some breaches of the moral right to constitute the crime of counterfeiting. 
from the treatment of the work". Finally, section 225(4) lets authors elect to use existing legal remedies, such as defamation, as well as or instead of the moral rights provisions.

\section{B Remedies Should Not Prove Too Onerous on the Music Industry}

Breach of the right of paternity would result either in damages or in an injunction requiring those who broadcast or publish the sound recording to name the successful plaintiff as a contributor to the recording. However, as argued in Part IV, attribution practices in the recording and broadcasting industries already seem robust enough to satisfy the paternity requirements in article 5(1) of the Treaty. Thus, these remedies are unlikely to be needed.

The injunction as a remedy for breach of the right of integrity is at the heart of the animosity that many United States commentators hurl towards moral rights. For example, Professor Robert Gorman argues that "...proscriptions upon alterations...may inhibit creativity more than [they] foster creativity". ${ }^{151}$ The fear is that the right of integrity will give a "congressionally granted power of aesthetic veto to a wide range of creative contributors", ${ }^{152}$ allowing any collaborator in a sound recording to prevent any changes to that recording, thereby stifling its commercial exploitation. In reality, though, the provisions of the Copyright Act 1994 alleviate most of these fears.

First, where the plaintiffs have made the work under employment, the only remedy that they can obtain is a disclaimer dissociating themselves from the work. ${ }^{153}$ Since producers, sound engineers and most backing musicians are invariably employees, it is incorrect to assert that these collaborators wield an "aesthetic veto" that prevents remastering, re-mixing or sampling of that recording.

Secondly, even where the main performers are not employees and have not waived their moral rights over their sound recording, an injunction is not an automatic remedy. In Rostropovitch, the Court said that a disclaimer was the appropriate remedy because the conductor of the film soundtrack could not have the film withdrawn from circulation when everybody else involved was happy with the film. The interest that the other collaborators had in making their work available for the public had to take priority over the rights of one disgruntled collaborator. ${ }^{154}$ Since sound recordings too are collaborative

151 Gorman, above n 75, 422 .

152 Gorman, above n 75, 424.

153 Copyright Act 1994, ss 100(8) and 100(9) (literary, artistic, musical and dramatic works), and ss 101(4) and 101(5) (films).

154 Rostropovitch, above n 136, 372. 
works, a disclaimer might be the most appropriate way of balancing the collaborators' competing interests.

Thirdly, it should be noted that the moral right in relation to musical works can be breached by issuing to the public copies of a sound recording containing a derogatory treatment of the musical work. ${ }^{155}$ Thus, withdrawing sound recordings from further circulation is already a possibility under current moral rights law, and indeed, this is precisely what happened in Morrison Leahy, ${ }^{156}$ when George Michael obtained an interlocutory injunction prohibiting the release of sound recordings that embodied a derogatory treatment of his musical works. The possibility of withdrawing sound recordings from further circulation because of a moral rights infringement thus already exists, so bringing sound recordings within the moral rights regime should not create any new problems.

Finally, traditional copyright law already allows performers to "ban" sampling of their work if they still hold the copyright in either the sound recording or the underlying musical work. In 1987, ABBA used their copyright over the musical work and sound recording of "Dancing Queen" to threaten the group JAMS with an injunction to prohibit them from issuing an album containing samples of "Dancing Queen". JAMS withdrew the album to avoid legal action. ${ }^{157}$ Since traditional copyright interests are already being used to restrain sampling practices, moral rights are hardly creating anything novel in the area of injunctions.

Certainly, injunctions could pose some problems in the area of sound recordings, which are collaborative works created specifically with commercial exploitation in mind. However, use of the injunction as a remedy will prove very limited in practice. Certainly, an injunction will be most effective only where it can be executed before infringing copies of the sound recording are released to the public, as George Michael managed to do in Morrison Leahy. Once copies of the infringing sound recording have been sold to the public, equity would probably not allow them to be recalled from these innocent third parties. ${ }^{158}$ On a practical level, too, withdrawal of CDs once sold would be impossible, given that CDs are sold in much greater quantities than most other copyright works.

155 Copyright Act 1994, s 99(1)(b).

156 Morrison Leahy, above n 122.

157 Simon Frith "Morality and Music" in Simon Frith (ed) Copyright and Music (Edinburgh University Press, Edinburgh, 1993), 5.

158 Third parties' interests must be considered in an application for an interlocutory injunction: Finnigan v New Zealand Rugby Football Union (No 2) [1985] 2 NZLR 181, 188 (HC) per Casey J. 
In respect of record companies' later release of discarded versions of sound recordings without the performers' consent (as in the Little River Band example), record companies can hardly claim that they are "burdened" if they are prevented from doing this. The main reason why record companies release these alternative versions is to try to capitalise a second time on the recording. This "double-dipping" should not trump the performers' right to have their recording left the way they wanted it to sound, but ultimately, the issue of discarded recordings might best be regulated in the contract between the record company and the performers.

\section{Conclusion}

If moral rights are extended to sound recordings in New Zealand, it is most improbable that the use of injunctions to remedy moral rights breaches over sound recordings will arise with sufficient frequency to knell the death of the music industry. Employees and those who have effected waivers over their moral rights are automatically disqualified from claiming equitable relief. Indeed, since the current waiver system in the Copyright Act is wide enough to "drive a coach and horses through" the moral rights provisions, ${ }^{159}$ record companies should easily be able to immunise themselves against the threat that injunctions might pose to the unfettered commercial exploitation of sound recordings.

In those rare cases where performers are not employees and have resisted pressure to waive their moral rights, injunctions will not always follow. Disclaimers are more likely where "the cost involved in avoiding the infringement altogether would be excessive compared with the particular harm involved". ${ }^{160}$ Furthermore, disclaimers are more likely in collaborative works where the various collaborators have differing views as to whether their sound recording has been given a "derogatory treatment". Ultimately, moral rights protection is a "question of fundamental fairness between author and work user". ${ }^{161}$ It will require a balancing of all the interests involved (including the interests of the record company) to determine the best remedy for an aggrieved plaintiff. Extending moral rights to sound recordings is thus unlikely to be too onerous a burden on the recording industry.

\section{CONCLUSION}

The fundamental principle from which this paper has been argued is that sound recordings are imbued with sufficient skill, creativity and human spirit for them to be brought logically within the scope of moral rights protection. The failure to extend moral rights to sound recordings seems to have been an accident of history, because moral rights

159 Dworkin, above n 93, 257.

160 Dworkin, above n 93, 255-256.

161 Dietz, above n 119, 225. 
were added to the Berne Convention while the recording industry was in its infancy. Article 5(1) of the WIPO Performances and Phonograms Treaty is a belated but welcome step in ending this anomaly, and this paper has sought to argue that moral rights can be extended to sound recordings without detrimental consequences for the music industry.

While writing this paper, the present author examined a number of United States commentaries on the moral rights issue. These articles, however, were particularly unhelpful in informing the discussion in this paper, because they were all written from the distinctive United States perspective of copyright law, which has constitutional parameters and pervading philosophies that are of very limited relevance in New Zealand. ${ }^{162}$ However, the recurring theme to be garnered from these articles is that every copyright regime has its own objectives and underlying philosophies. Therefore, it is appropriate to consider what is best for New Zealand in determining whether it would be desirable for moral rights to be extended to sound recordings under New Zealand law.

When the WIPO Performances and Phonograms Treaty was being thrashed out at a diplomatic conference in December 1996, New Zealand proposed an amendment that Contracting Parties be allowed to enter a reservation over the moral rights provisions of article 5. ${ }^{163}$ However, the diplomatic conference rejected New Zealand's proposal and made moral rights an obligatory part of the Treaty for every Contracting Party. New Zealand, in turn, rejected the idea of signing the Treaty.

The New Zealand position seems to have been influenced by submissions to the Ministry of Commerce from Television New Zealand, Radio New Zealand and the Radio Broadcasters Association, all of which opposed article 5. The Recording Industry Association of New Zealand (RIANZ) also opposed the provision, claiming (unsurprisingly) that moral rights would lead to "practical difficulties" in naming all the performers and that it might lead to the possible prohibition of re-mixing, "a very necessary and often used practice in the recording industry". ${ }^{164}$ As this paper has argued, however, the implementation of moral rights over sound recordings is unlikely to bring these detrimental consequences for the broadcasting and recording industries. The cogency of the RIANZ's arguments in this regard is therefore open to some question.

With respect, the present author believes that the New Zealand position on moral rights in relation to sound recordings is rather myopic. With the United Kingdom

162 Beyer, above n 107, 1022.

163 Delegation of New Zealand Amendment to Article 25 of Draft Treaty No 2: CRNR/DC/46 (World Intellectual Property Organisation, Geneva, 1996).

164 Recording Industry Association of New Zealand Inc "Submission on WIPO Draft Treaties" (15 October 1996) 7. 
examining how to implement the Treaty into its law, ${ }^{165}$ it seems likely that the Treaty will soon come into force, in which case New Zealand may well need to re-examine its position. In any event, the present author would suggest that recent political events in New Zealand make it timely to take a second look at the issue.

The new Labour-Alliance Government, with Prime Minister Helen Clark at the helm, has made the arts a priority area. On 18 May 2000, the Government announced an immediate funding boost for the arts of $\$ 86$ million, and promised $\$ 60$ million over the following three years. ${ }^{166}$ Yet, the editorial in the Listener noted that the arts in New Zealand were still left with "chronic structural problems". ${ }^{167}$ The present author wishes to suggest that the extension of moral rights to cover sound recordings could be one plank in a platform for alleviating some of these "chronic structural problems".

The problem with arts in New Zealand is that it is difficult for artists to make a living from the arts. Dr Adolf Dietz observes that the main interest of professional authors in having a moral right might be economic. Their talent becomes known only when they can attach their name to their products, and they may insist on the integrity of their work in order to maintain a reputation that will permit them to keep on selling new works. ${ }^{168}$ Thus, moral rights might assist performing artists in New Zealand (at least to some extent) to build and to maintain for themselves reputations that will allow them to make a satisfactory living from working as recording artists.

Ultimately, deciding how best to extend moral rights to sound recordings is a question of balance. Furthermore, this question must be answered in light of the technological evolution in the music industry. The technology that permits sampling can also lead to unemployment, as the demand for live performers diminishes. ${ }^{169} \mathrm{New}$ digital technology is also allowing sound recordings to be manipulated in new ways, which makes the need for a right of integrity over sound recordings more pressing. ${ }^{170}$ Yet, the public also seems to enjoy listening to sampled or re-mixed works. At the time of writing, the New Zealand

165 See above Part I.

166 "Heart for Art's Sake" New Zealand Listener, Auckland, New Zealand, 3-9 June 2000, 7.

167 "Heart for Art's Sake", above n 166, 7.

168 Dietz, above n 119, 211.

169 See Teller, above n 36, 775.

170 Rebecca F Martin "The WIPO Performances and Phonograms Treaty: Will the US Whistle a New Tune?" (1997) 44 J Copyright Soc'y USA 157, 167. 
Top 50 Singles Chart has at least two singles that involve a new group of artists re-working an actual sound recording from an earlier band. ${ }^{171}$

The present author believes that the regime proposed in this paper for moral rights in relation to sound recordings provides a fair balance between these competing interests. Allowing producers and sound engineers to have access to the moral right seems only fair and logical, given that they too infuse the sound recording with some of its creative spark. In determining what constitutes a breach of the right of integrity, it would seem sensible too to give weight to the collaborators' opinions on whether their "honour or reputation" had been prejudiced. Careful control of the use of the various remedies will ensure that the interests of record companies and the listening public are not adversely affected by the implementation of these new rights.

There seems no valid reason why sound recordings should be excluded from the ambit of moral rights when every other creative work in the copyright regime receives moral rights protection. In the interests of those who create sound recordings, and in the interests of the internal consistency of the current copyright regime, the present author recommends that the moral rights regime proposed in this paper should be enacted for sound recordings under New Zealand law.

171 The singles are "We Will Rock You" by Five and Queen, and "Sundown" by Elwood: $<$ http:/ / w w w.top50.co.nz> (last accessed 10 September 2000). Curiously, both CD singles respect the right of paternity of the original artist if not the right of integrity. 
